\title{
Psychology service delivery at the Royal Melbourne Hospital Eating Disorder Unit
}

\author{
Megan Dobbie \\ From 2013 ANZAED Conference: Inspiring Change: Person and Context \\ Melbourne, Australia. 23-24 August 2013
}

This poster will outline the psychology services available to inpatients and outpatients who present for treatment at the Royal Melbourne Hospital Eating Disorder Unit. A brief outline of the inpatient, outpatient, and daypatient psychological services will be provided with clear rationales for the basis for offering the service delivery approaches. In addition, the role psychology on the unit as a function of a multipdiscplinary team and therapeutic milleu will be outlined. Future directions for psychology and the role the psychologists working on the unit play in research projects and areas of research interest will also be outlined in this poster.

Published: 14 November 2013

doi:10.1186/2050-2974-1-S1-P4

Cite this article as: Dobbie: Psychology service delivery at the Royal

Melbourne Hospital Eating Disorder Unit. Journal of Eating Disorders 2013

1(Suppl 1):P4.

Correspondence: Megan.Dobbie@mh.org.au

Eating Disorders Unit, NorthWestern Mental Health, Royal Melbourne

Hospital, Australia

Submit your next manuscript to BioMed Central and take full advantage of:

- Convenient online submission

- Thorough peer review

- No space constraints or color figure charges

- Immediate publication on acceptance

- Inclusion in PubMed, CAS, Scopus and Google Scholar

- Research which is freely available for redistribution 